\title{
COMPARISON OF DIFFERENT PROTOCOLS FOR THE EXTRACTION OF MICROBIAL DNA FROM REEF CORALS
}

Santos, H.F. ${ }^{1}$; Carmo, F.L. ${ }^{1}$; Leite, D.C.A. ${ }^{1}$; Jesus, H.E. ${ }^{1}$; De Carvalho Maalouf, P. ${ }^{1,2}$; Almeida, C. ${ }^{\text {; }}$ Soriano, A.U. ${ }^{3}$; Altomari, D. ${ }^{4}$; Suhett, L. ${ }^{3}$; Vólaro, V. ${ }^{4}$; Valoni, E. ${ }^{3}$; Francisco, M. ${ }^{3}$; Vieira, J. $^{3}$; Rocha, R. ${ }^{4}$; Sardinha, B.L. ${ }^{3}$; Mendes, L.B. ${ }^{3}$; João, R.R. ${ }^{3}$; Lacava, B. ${ }^{3}$; Jesus, R.F. ${ }^{3}$; Sebastian, G.V. ${ }^{3}$; Pessoa, A. ${ }^{5}$; van Elsas, J.D. ${ }^{6}$; Rezende, R.P. ${ }^{8}$; Pires, D.O. ${ }^{7,9}$; Duarte, G. ${ }^{7,9}$; Castro, C.B. ${ }^{7,9}$; Rosado, A.S. ${ }^{1,9}$; Peixoto, R.S. ${ }^{1,9}$

${ }^{1}$ Laboratório de Ecologia Molecular Microbiana, Universidade Federal do Rio de Janeiro, Rio de Janeiro, RJ, Brasil; ${ }^{2}$ Protein Engineering Center, Institute of Chemistry, University of Liege, Belgium; ${ }^{3}$ Gerência de Biotecnologia, Centro de Pesquisas Leopoldo Américo Miguez de Mello, Petrobras, Rio de Janeiro, RJ, Brasil; ${ }^{4}$ Fundação Gorceix, Ouro Preto, MG, Brasil; ${ }^{5}$ Faculdade de Ciências Farmacêuticas, Universidade de São Paulo, SP, Brasil; ${ }^{6}$ Department of Microbial Ecology, University of Groningen, Groningen, The Netherlands; ${ }^{7}$ Departamento de Invertebrados, Museu Nacional, Universidade Federal do Rio de Janeiro, Rio de Janeiro, RJ, Brasil; ${ }^{8}$ Universidade Estadual de Santa Cruz, Ilhéus, BA, Brasil; ${ }^{9}$ Projeto Coral Vivo, Universidade Federal do Rio de Janeiro, Rio de Janeiro, RJ, Brasil.

Submitted: December 10, 2011; Approved: June 07, 2012.

\begin{abstract}
This study aimed to test different protocols for the extraction of microbial DNA from the coral Mussismilia harttii. Four different commercial kits were tested, three of them based on methods for DNA extraction from soil (FastDNA SPIN Kit for soil, MP Bio, PowerSoil DNA Isolation Kit, MoBio, and ZR Soil Microbe DNA Kit, Zymo Research) and one kit for DNA extraction from plants (UltraClean Plant DNA Isolation Kit, MoBio). Five polyps of the same colony of M. harttii were macerated and aliquots were submitted to DNA extraction by the different kits. After extraction, the DNA was quantified and PCR-DGGE was used to study the molecular fingerprint of Bacteria and Eukarya. Among the four kits tested, the ZR Soil Microbe DNA Kit was the most efficient with respect to the amount of DNA extracted, yielding about three times more DNA than the other kits. Also, we observed a higher number and intensities of DGGE bands for both Bacteria and Eukarya with the same kit. Considering these results, we suggested that the ZR Soil Microbe DNA Kit is the best adapted for the study of the microbial communities of corals.
\end{abstract}

Key words: coral, microbial diversity, DNA extraction.

\section{INTRODUCTION}

Among the ecosystems that are responsible for maintaining the diversity of life in the oceans, coral reefs have long been recognized as the most important. They are among the systems that support the greatest biodiversity and thus offer the most valuable benefits to man. About $30 \%$ of all marine life in the oceans is present in coral reef ecosystems, which

\footnotetext{
*Corresponding Author. Mailing address: Laboratory of Molecular Microbiology, Federal University of Rio de Janeiro (UFRJ), Rio de Janeiro, Brazil.; E-mail: raquelpeixoto@micro.ufrj.br
} 
account for only $0.20 \%$ of the ocean area $(15,17)$. Conversely, corals are under serious threat because of anthropogenic activities as well as environmental changes caused by global warming, such as rising temperatures and ocean acidification $(6,12)$. While about $30 \%$ of reefs worldwide have already been seriously damaged, $60 \%$ of them are in danger of being completely lost by 2030 (26). On the bright side, recent studies have revealed particular physiological mechanisms that improve the resilience of corals to the effects of climate change and anthropogenic activities (12).

Recently, it was postulated that corals need a diverse community of microorganisms to live healthily, this association is called holobiosis $(2,19,21)$. This resulted in the hologenome concept, where the genome of the host can act in concert with the genomes of the associated symbiotic microorganisms, providing the holobiont organism with greater adaptive potential. To understand the role of microorganisms in the survival and evolution of corals, it is extremely important to carry out studies on the composition, structure and functional activity of the microbial community associated with healthy as well as diseased corals from different regions.

Studies on the microbial communities in different environments have shown that about $90.0 \%$ to $99.9 \%$ of the microbial community is often not cultivable by the traditional techniques of microbiology (7). For this reason, to carry out a survey of the microbial diversity associated with a particular environment or organism, such as corals, it is critical to use direct molecular techniques. The DNA extraction from the samples is the first critical step in any molecular technique based on DNA (12). However, there is a paucity of DNA extraction methods that have been successfully applied to corals. Therefore, this study aimed to test four different methods of DNA extraction from coral: three kit-based methods for DNA extraction from soil (FastDNA SPIN Kit for soil, PowerSoil DNA Isolation Kit, MoBio, and ZR Soil Microbe DNA Kit, Zymo Research) and one kit for DNA extraction from plants (UltraClean Plant DNA Isolation Kit, Mobio).

\section{MATERIALS AND METHODS}

\section{Site and sample collection}

A colony of Mussismilia harttii was collected from a reef area off Porto Seguro, Bahia, Brazil (circa 16 29'28,8' S and $039^{\circ} 03$ ' $\left.49,9^{\prime \prime} \mathrm{W}\right)$, on a $2 \mathrm{~m}$ depth fringing reef at $400 \mathrm{~m}$ of the coast.

\section{Preparation of coral samples}

Five polyps of the same colony were separated in small pieces of approximately $1 \mathrm{~g}$ each, containing mucus, tissue and skeleton. They were macerated in a mortar in dry condition using a pestle before proceeding with the different extraction protocols.

\section{DNA extraction and quantification}

For this study we tested four different methods of DNA extraction: the FastDNA SPIN Kit for soil (Method F), the PowerSoil DNA Isolation Kit (Method P), the ZR Soil Microbe DNA Kit (Method Z) and the UltraClean Plant DNA Isolation Kit (Method U).

The FastDNA SPIN Kit for soil was designed to isolate bacterial, fungal, plant and animal genomic DNA from soil and other environmental samples, such as feces, environmental water, wastewater and sludge. The PowerSoil DNA Isolation Kit is ideal for processing all types of environmental samples including most difficult ones with high contents of humic acid such as compost, sediment and manure. This Kit distinguishes itself from others with a patented procedure that eliminates PCR inhibitors (humic substance) from the most difficult soil types, promoting successful downstream PCR analysis. The ZR Soil Microbe DNA Kit ${ }^{\mathrm{TM}}$ is designed to isolate humic-free, PCR-quality genomic DNA from microbes in soil. The kit can be used to successfully isolate DNA from 
tough-to-lyse bacteria, fungi, protozoa, and algae that inhabit a range of samples including clay, sandy, silty, peaty, chalky, and loamy soils. The UltraClean ${ }^{\circledR}$ Plant DNA Isolation Kit is designed to purify total cellular DNA from plant cells and tissues. For all kits, we followed the manufacturer's instruction with some modifications to perform the extractions.

\section{Method F - The FastDNA SPIN Kit for soil}

Up to $500 \mathrm{mg}$ of sample was added to $978 \mu \mathrm{L}$ of Sodium Phosphate Buffer and $122 \mu \mathrm{L}$ of MT Buffer in Lysing Matrix E tubes. The mixture was homogenized in the FastPrep $\mathbb{R}$ machine for $40 \mathrm{~s}$ at a speed setting of 6.0 , after which it was centrifuged at $14,000 \times \mathrm{g}$ for 5-10 min to pellet debris. The supernatant was transferred to a clean $2.0 \mathrm{~mL}$ microcentrifuge tube. After this, $250 \mu \mathrm{L}$ PPS (Protein Precipitation Solution) was added, and the solution was mixed manually by shaking 10 times the tubes. Then, centrifugation was performed at 14,000 $\mathrm{x} g$ for $5 \mathrm{~min}$ to pellet the precipitate, after which the supernatant was transferred to a clean $15 \mathrm{~mL}$ tube. The Binding Matrix was resuspended and $1 \mathrm{~mL}$ was added to the supernatant in the $15 \mathrm{~mL}$ tube. Next, the tubes were inverted by hand for 2 min to allow binding of DNA and kept still for 3 min to allow settling of the silica matrix. Then, $500 \mu \mathrm{L}$ of the supernatant were removed and discarded, being careful to avoid the settled Binding Matrix containing the DNA. The Binding Matrix was then resuspended in the remaining supernatant. Then, approximately $600 \mu \mathrm{L}$ of the mixture was transferred to a SPINTM Filter and centrifuged at $14,000 \times \mathrm{g}$ for $1 \mathrm{~min}$. The catch tubes were emptied and the remaining mixture was added to the SPINTM Filter and centrifuged as before. The catch tubes were emptied again. At this step, a pellet is formed above the SPINTM Filter, $500 \mu \mathrm{L}$ of prepared SEWS-M wash solution is added in order to gently resuspended it using the force of the liquid from the pipette tip. The catch tubes were centrifuged at $14,000 \mathrm{x} g$ for $1 \mathrm{~min}$, after which they were emptied and replaced. Without any addition of liquid, the system was centrifuged a second time at $14,000 \times \mathrm{g}$ for 2 min to "dry" the matrix of residual wash solution. The catch tubes were discarded and replaced with clean ones. The

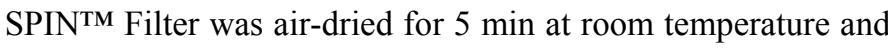
the Binding Matrix was gently resuspended (above the SPIN filter) in 50-100 $\mu \mathrm{L}$ of DES (DNase/Pyrogen-Free Water).

Finally, a centrifugation step at $14,000 \mathrm{x} \mathrm{g}$ for $1 \mathrm{~min}$ brings the eluted DNA into the clean catch tubes and is now ready for any downstream application.

\section{Method P - The PowerSoil DNA Isolation Kit}

The kit provides PowerBead Tubes to which $0.25 \mathrm{mg}$ of each coral sample were added and the tubes are mixed by gentle vortexing. Then $60 \mu \mathrm{L}$ of Solution $\mathrm{C} 1$ were added and the tubes were vortexed for 5 seconds. After a centrifugation step at $10,000 \times \mathrm{g}$ for 30 seconds at room temperature, the supernatant was transferred to a clean $2 \mathrm{~mL}$ Collection Tube. Then $250 \mu \mathrm{L}$ of Solution $\mathrm{C} 2$ were added and the tubes were vortexed for 5 seconds. Following that, the tubes were incubated at $4^{\circ} \mathrm{C}$ for $5 \mathrm{~min}$ and the centrifuged at room temperature for $1 \mathrm{~min}$ at $10,000 \mathrm{x}$. Then up $600 \mu \mathrm{L}$ of supernatant were transferred to a clean $2 \mathrm{~mL}$ Collection Tube avoiding the pellet. $200 \mu \mathrm{L}$ of Solution C3 were added and the tubes were briefly vortexed and incubated at $4{ }^{\circ} \mathrm{C}$ for $5 \mathrm{~min}$. The mixtures were centrifuged at room temperature for $1 \mathrm{~min}$ at $10,000 \mathrm{x}$. Then, up to $750 \mu \mathrm{L}$ of supernatant were transferred to a clean $2 \mathrm{~mL}$ Collection Tube. Then $1200 \mu \mathrm{L}$ of Solution C4 were added to the supernatant and the mixtures vortexed for 5 seconds. Approximately $675 \mu \mathrm{L}$ of the mixture were loaded onto a Spin Filter and centrifuged at 10,000 x g for $1 \mathrm{~min}$ at room temperature. The flow through was discarded, an additional $675 \mu \mathrm{L}$ of supernatant was added to the Spin Filter and centrifuged at $10,000 \times \mathrm{g}$ for $1 \mathrm{~min}$ at room temperature. The same was done with the remaining volume of supernatant. Then $500 \mu \mathrm{L}$ of Solution C5 were added and centrifuged at room temperature for 30 seconds at $10,000 \mathrm{x}$ g. After discarding the flow through, the samples were centrifuged again at room temperature for $1 \mathrm{~min}$ at $10,000 \mathrm{x} \mathrm{g}$ and the 
Spin Filters were placed in a clean $2 \mathrm{~mL}$ Collection Tube with care not to splash them with the flow through. Then $100 \mu \mathrm{L}$ of Solution C6 were added to the center of the white filter membrane. Centrifugation was performed at room temperature for 30 seconds at 10,000 x $\mathrm{g}$ and the Spin Filter was discarded. The DNA in the tube is now ready for any downstream application.

\section{Method Z - The ZR Soil Microbe DNA Kit'M Short Protocol}

For this Kit was added up to $0,5 \mathrm{~g}$ of coral sample to a $\mathrm{ZR}$ BashingBead $^{\mathrm{TM}}$ Lysis Tube. The tubes were homogenized in the FastPrep ${ }^{\circledR}$ for 40 seconds at a speed setting of 6.0 and centrifuged at $14,000 \times \mathrm{g}$ for $1 \mathrm{~min}$. Then $400 \mu \mathrm{L}$ of the supernatant were transferred up to a Zymo-Spin ${ }^{\mathrm{TM}}$ IV Spin Filter (orange top) in a Collection Tube and centrifuged at $14,000 \times \mathrm{g}$ for $1 \mathrm{~min}$. Next 1,200 $\mu \mathrm{L}$ of Soil DNA Binding Buffer were added to the filtrate in the Collection Tube and a volume of $800 \mu \mathrm{L}$ of this mixture was transferred to a ZymoSpin $^{\mathrm{TM}}$ II Column in a Collection Tube. The mixture was centrifuged at $10,000 \mathrm{x} \mathrm{g}$ for $1 \mathrm{~min}$. The flow through was discarded and another $800 \mu \mathrm{L}$ of the mixture was transferred to the Zymo-Spin ${ }^{\mathrm{TM}}$ II Column and the same centrifugation was performed. Then the Zymo-Spin ${ }^{\mathrm{TM}}$ II Column was transferred to a new Collection Tube and $200 \mu$ of DNA Pre-Wash Buffer were added and centrifuged at 10,000 x g for $1 \mathrm{~min}$. After that, $500 \mu \mathrm{L}$ of Soil DNA Wash Buffer were added to the ZymoSpin $^{\mathrm{TM}}$ II Column and centrifuged at $10,000 \mathrm{x} \mathrm{g}$ for $1 \mathrm{~min}$. The Zymo-Spin ${ }^{\mathrm{TM}}$ II Column was transfered to a clean $1.5 \mathrm{~mL}$ microcentrifuge tube and $100 \mu \mathrm{L}$ of DNA Elution Buffer were added directly to the column matrix. Next a centrifugation was performed at $10,000 \times \mathrm{g}$ for 30 seconds to elute the DNA. Finally, the eluted DNA was transferred to a prepared ZymoSpin $^{\mathrm{TM}}$ IV-HRC Spin Filter (green top) in a clean $1.5 \mathrm{~mL}$ microcentrifuge tube and was centrifuged at 8,000 $\mathrm{x} g$ for 1 min. The filtered DNA is now suitable for PCR and other downstream applications.

\section{Method U - UltraClean Plant DNA Isolation Kit}

In this kit, $200 \mathrm{mg}$ of sample are needed for the extraction. The weighted coral was mixed with $60 \mu \mathrm{L}$ of Solution P1 in the $2 \mathrm{~mL}$ Bead Solution tubes by slight vortexing. Next, the tubes were incubated in a water bath at $65^{\circ} \mathrm{C}$ for overnight. The next day, the tubes were homogenized in the FastPrep ${ }^{\circledR}$ for 40 seconds at a speed setting of 6.0 and centrifuged at 10,000 x g for 30 seconds. The supernatant was transferred to a clean 2 $\mathrm{mL}$ Collection Tube. $250 \mu \mathrm{L}$ of Solution P2 were added and the mixture was vortexed for 5 seconds and incubated at $4^{\circ} \mathrm{C}$ for $5 \mathrm{~min}$. Then the tubes were centrifuged for $1 \mathrm{~min}$ at 10,000 $\mathrm{x}$ g. Avoiding the pellet, $500 \mu \mathrm{L}$ of the supernatant was transferred to a clean $2 \mathrm{~mL}$ Collection Tube and $1 \mathrm{~mL}$ of solution P3 were added (be careful to shake the Solution P3 before use). Vortex 5 seconds to mix the sample with the solution. Load approximately $650 \mu \mathrm{L}$ onto the Spin Filter, centrifuge at $10,000 \times \mathrm{g}$ for 30 seconds and discard the flow through Repeat this step with the remaining volume of sample. Then $300 \mu \mathrm{L}$ of Solution P4 was added and the Spin Filters were centrifuged for 30 seconds at $10,000 \mathrm{x}$. The flow through was discarded and the filters centrifuged again to remove residual Solution P4. Carefully place the Spin Filter in a new clean $2 \mathrm{~mL}$ Collection and add $50 \mu \mathrm{L}$ of Solution P5 to the center of the white filter membrane and centrifuge for 30 seconds. The Spin Filter was discarded and DNA was preserved.

\section{Detection of the DNA produced}

The samples extracted by the four different commercials kits were evaluated for DNA concentration using the Qubit fluorometer. The amount, average size and quality of the DNA were further assessed using conventional electrophoresis in agarose gels.

\section{PCR-DGGE of 16S and 18S rDNA}

Amplification of specific regions of the gene encoding the 16S rRNA was performed using the primers U968f (5' GC clamp + AAC GCG AAG AAC CTT AC 3') and L1401r (5' GCG TGT GTA CAA GAC CC 3') (8). The amplification was 
performed in a solution containing $1 \mathrm{X}$ PCR buffer, $0.2 \mathrm{mM}$ of dNTP , $2.5 \mathrm{mM}$ of $\mathrm{MgCl}_{2}, 2.5 \mathrm{U}$ of recombinant Taq DNA polymerase (Promega), $10 \mathrm{ng}$ of total DNA, $200 \mu \mathrm{mol}$ of each primer and sterile Milli-Q water for a final volume of $50 \mu \mathrm{L}$. The reaction was performed in a Mastercycler Gradient (Eppendorf, Hamburg, Germany) under the following conditions: initial denaturation at $94^{\circ} \mathrm{C}$ for $3 \mathrm{~min}, 35$ cycles at $94^{\circ} \mathrm{C}$ for $1 \mathrm{~min}, 55^{\circ} \mathrm{C}$ for $1 \mathrm{~min}$ and $72{ }^{\circ} \mathrm{C}$ for $1 \mathrm{~min}$ with a final extension at $72{ }^{\circ} \mathrm{C}$ for $10 \mathrm{~min}$.

The DGGE gels (30 to $65 \%$ of urea and formamide) were prepared with a solution of polyacrylamide $(6 \%)$ in Tris-acetate (pH 8.3). The run was performed in Tris-acetate-EDTA buffer at $60{ }^{\circ} \mathrm{C}$ at a constant voltage of $75 \mathrm{~V}$ for 16 hours. The DGGE gels were stained with Sybr Green (Molecular Probes) and visualized using a Storm 860 Imaging System (GE Healthcare).

The amplification of specific fragments of the gene encoding the $18 \mathrm{~S}$ ribosome subunit of the microeukaryotes was performed using the primers Ek7F-GC (3' ACCTGGTTGATCCTGCCAG + GC clamp 5') and EK516R (3' ACCAGACTTGCCCTCC5') $[5,21,30]$ generating a product with about $500 \mathrm{bp}$. The amplification was performed in a solution containing $1 \mathrm{X}$ PCR buffer, $0.2 \mathrm{mM}$ of dNTP, $2.0 \mathrm{mM}$ of $\mathrm{MgCl} 2,0.75 \mathrm{U}$ of recombinant Taq DNA polymerase (Promega), $10 \mathrm{ng}$ of total DNA, 5 pmol of each primer and sterile Milli-Q water for a final volume of $50 \mu \mathrm{l}$. The reaction was performed in a Mastercycler Gradient (Eppendorf, Hamburg, Germany) under the following conditions: initial denaturation at $94{ }^{\circ} \mathrm{C}$ for $30 \mathrm{sec}, 35$ cycles at 94
${ }^{\circ} \mathrm{C}$ for $30 \mathrm{sec}, 56{ }^{\circ} \mathrm{C}$ for $45 \mathrm{sec}$ and $72{ }^{\circ} \mathrm{C}$ for $130 \mathrm{sec}$ with a final extension at $72{ }^{\circ} \mathrm{C}$ for $7 \mathrm{~min}$.

The amplicons were then separated by denaturing gradient gel electrophoresis (DGGE). The run was performed as for the $16 \mathrm{~S}$ rDNA gene.

\section{RESULTS}

\section{Isolation of DNA from coral samples by four different techniques}

We successfully obtained agarose gel-detectable DNA from the coral samples using all four commercial DNA extraction kits. Electrophoresis on agarose gels revealed that all DNA was relatively large in size, estimated to range from 10-40 Kb (data not shown). Per method, the replicates were consistent in both average fragment size and quantity of DNA produced (Table 1). Overall, there was no significant difference in average fragment size between the different methods applied, which was $10-40 \mathrm{~Kb}$ in all extracts. The concentrations of DNA in the preparations obtained by the different methods (expressed as ng per $\mathrm{g}$ extracted coral tissue), as measured by Qubit and confirmed by estimates on gel were as follows: method $\mathrm{Z}, 3.7 \mathrm{ng} / \mu \mathrm{L}$ (1.1); method F, $1.2 \mathrm{ng} / \mu \mathrm{L}$ (0.9); method P, $0.9 \mathrm{ng} / \mu \mathrm{L}$ (0.1) and method U, $0.9 \mathrm{ng} / \mu \mathrm{L}$ (1.3) (Table 1). Furthermore, the triplicates of methods $Z$ and P showed a similar amount of DNA extracted from all replicas, revealing consistency in the extraction procedure. However, this was not seen when using methods $\mathrm{U}$ and F. In these methods, the yields fluctuated more wildly.

Table 1. DNA quantification after extraction and numbers of bands in the DGGE gel of Bacteria and Eukarya from coral Mussismilia harttii.

\begin{tabular}{lccc}
\hline & $\begin{array}{c}\text { DNA quantification after } \\
\text { extraction ng/ } \mathbf{L L}\end{array}$ & $\begin{array}{c}\text { Numbers of bands in the DGGE } \\
\text { gel / Bacteria }\end{array}$ & $\begin{array}{c}\text { Numbers of bands in the DGGE } \\
\text { gel / Micro-eukaryotes }\end{array}$ \\
\hline Method Z & & & 7 \\
replicate 1 & 3.06 & 36 & 8 \\
replicate 2 & 4.98 & 36 & 6 \\
replicate 3 & 3.04 & 35 & - \\
Method F & & & - \\
replicate 1 & 2.27 & 25 & - \\
replicate 2 & 0.93 & 26 & 1 \\
replicate 3 & 0.46 & 27 & 1 \\
Method P & & & 1 \\
replicate 1 & 0.95 & 31 & \\
replicate 2 & 0.85 & 28 & 1 \\
replicate 3 & 0.87 & 32 & 1 \\
Method U & & & 1 \\
replicate 1 & 0.20 & 32 & \\
replicate 2 & 0.21 & 29 & \\
replicate 3 & 2.40 & 29 & \\
\hline
\end{tabular}


Concerning the yields, the amount of DNA extracted with method $Z$ was about three times higher than those with methods $\mathrm{F}$ and $\mathrm{P}$ and about four times higher than the yield of method U. Thus, method $\mathrm{Z}$ appears as a suitable method for further exploration of the coral-associated (micro) biota.

\section{PCR-DGGE analyses}

Using both bacterial and micro-eukaryote primers, PCR amplification was successful with the DNA obtained from all samples. The amplicons were first checked on agarose gel to assess their size and quantity. In all cases, we obtained amplicons of the expected sizes, i.e. about $450 \mathrm{bp}$, in considerable amounts. The mixed amplicons were then separated by denaturing gradient gel electrophoresis (DGGE).

Bacteria: The amplicons generated from the differentlyextracted DNAs yielded diverse banding patterns on DGGE (Fig. 1). These patterns were highly similar between the replicates of DNA extracted with the same method, yet there were clear differences between the patterns of DNA generated from different methods. Thus, DNA extraction method clearly affects observed the bacterial diversity in coral samples. The bacterial PCR-DGGE profiles demonstrated that method
Z, compared to all the other extraction methods that were tested, revealed a profile with more intense bands (Fig. 2 and 4) as well as a higher number of bands (Tab. 1). The method Z showed an average of 35.6 bands (1.1), followed by method $\mathrm{P}$ with 30.3 (2.0), method U with 30 (1.7) and method F with 26 (2.0). The number of DGGE bands of samples submitted to method $\mathrm{Z}$ was about $37 \%$ higher than in method $\mathrm{F}$. In terms of evenness, the patterns generated by method $\mathrm{P}$ were closest to those generated by method $\mathrm{Z}$, but the number and intensity of bands in the DGGE gels were lower (Fig. 2 and 4).

Micro-eukaryotes: The 18S rRNA gene yielded visible banding patterns in most of the tested methods, except method F (Fig. 3); in all cases, the replicates were quite consistent, indicating consistency in the extraction procedure. However, there were pronounced differences in the DGGE band profiles between the different methods. As for the DGGE results of the $16 \mathrm{~S}$, the $18 \mathrm{~S}$ profiles gave a higher number of bands and higher intensities with DNA extracted by method Z compared to the other methods (Fig. 3). Method Z showed 7, 8 and 6 bands in the replicates 1, 2 and 3 respectively, while methods $U$ and $P$ could only reveal one band in all replicates. As said earlier, method $\mathrm{F}$ failed to give any band from all three replicates.

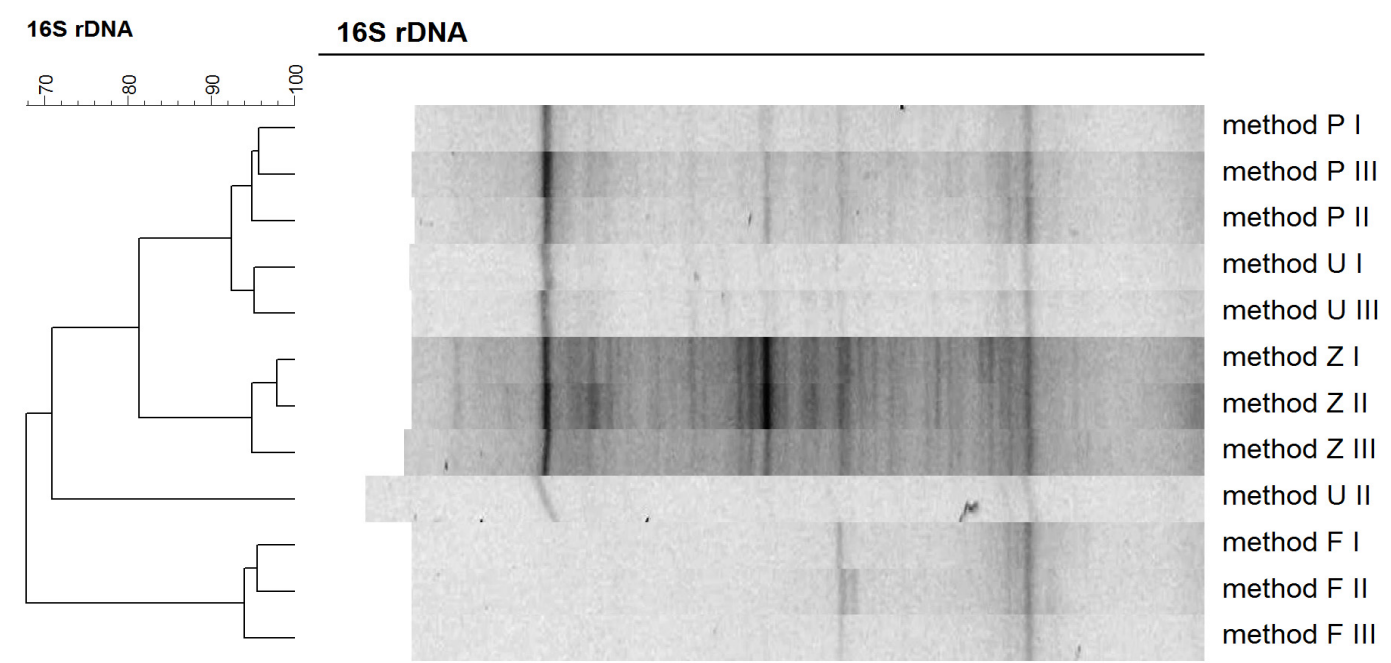

Figure 1. DGGE profiles of PCR-amplified SSU rRNA gene fragments of Bacteria. Triplicate samples were used. Clustering analysis was based on Pearson's correlation index and the unweighted pair-group method with arithmetic averages. Method F: FastDNA SPIN Kit for soil. Method P: PowerSoil DNA Isolation Kit. Method Z: ZR Soil Microbe DNA Kit .Method U UltraClean Plant DNA Isolation Kit. 


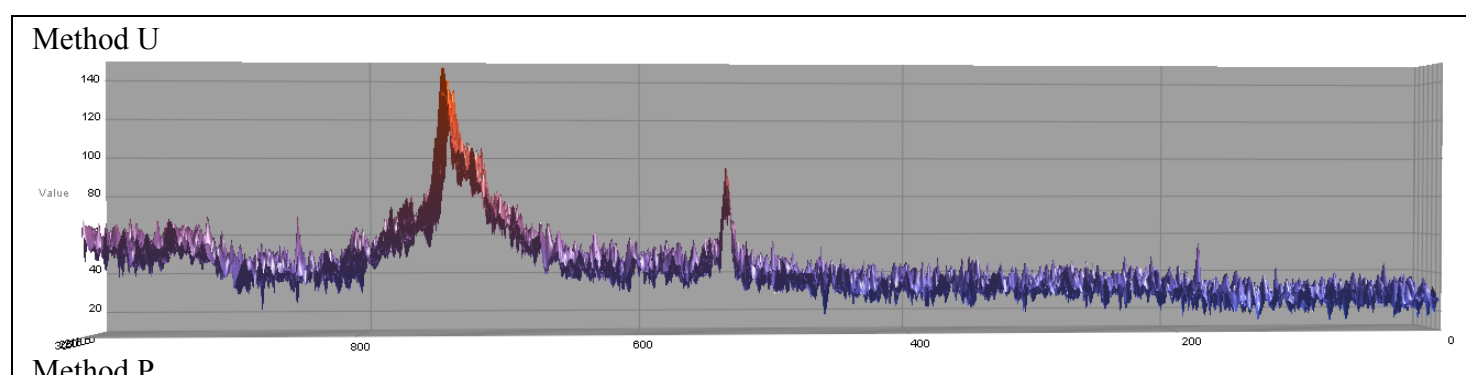

Method P

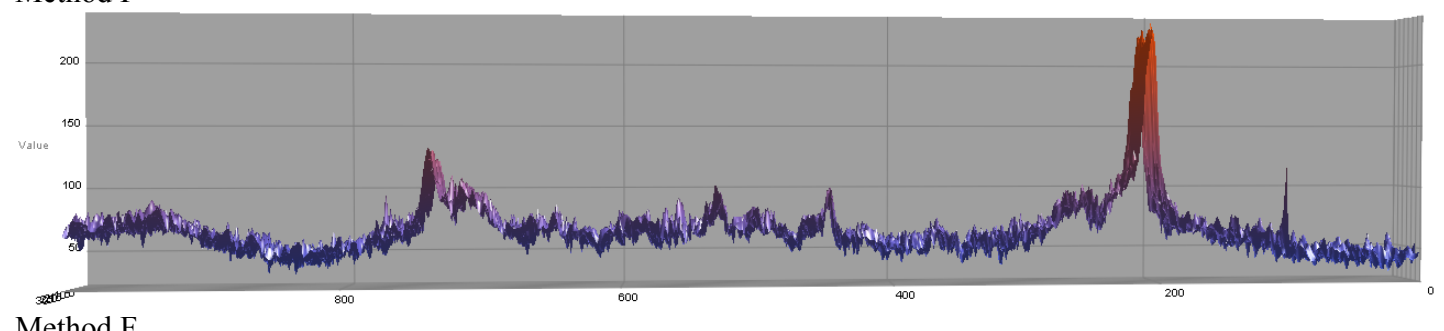

Method F

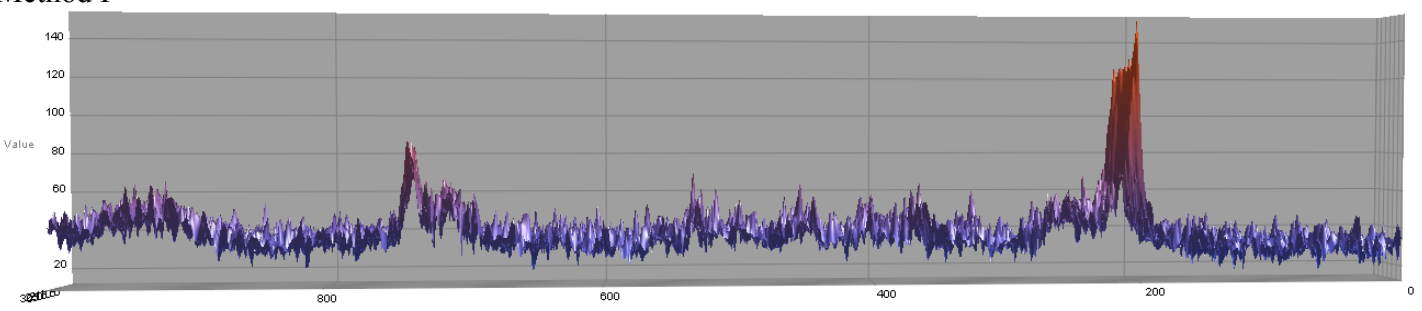

Method Z

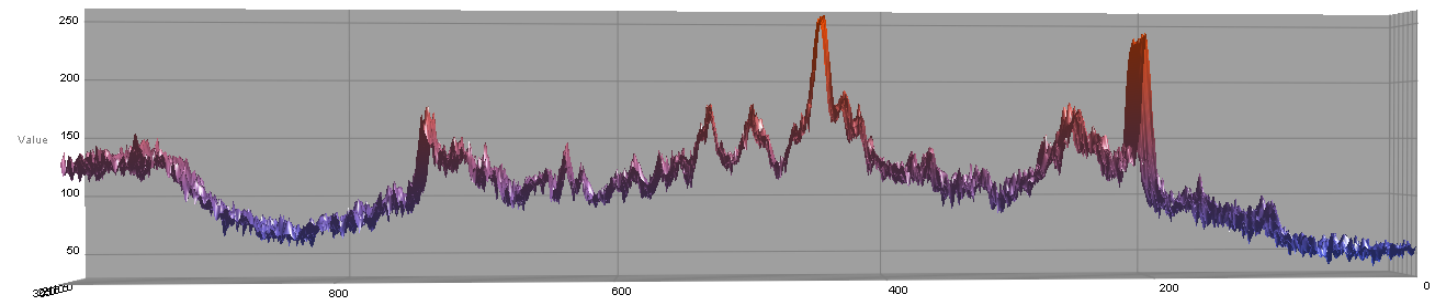

Figure 2. Intensity of bands in the DGGE profiles of PCR-amplified SSU rRNA gene fragments of Bacteria evaluated by the program BioNumerics.

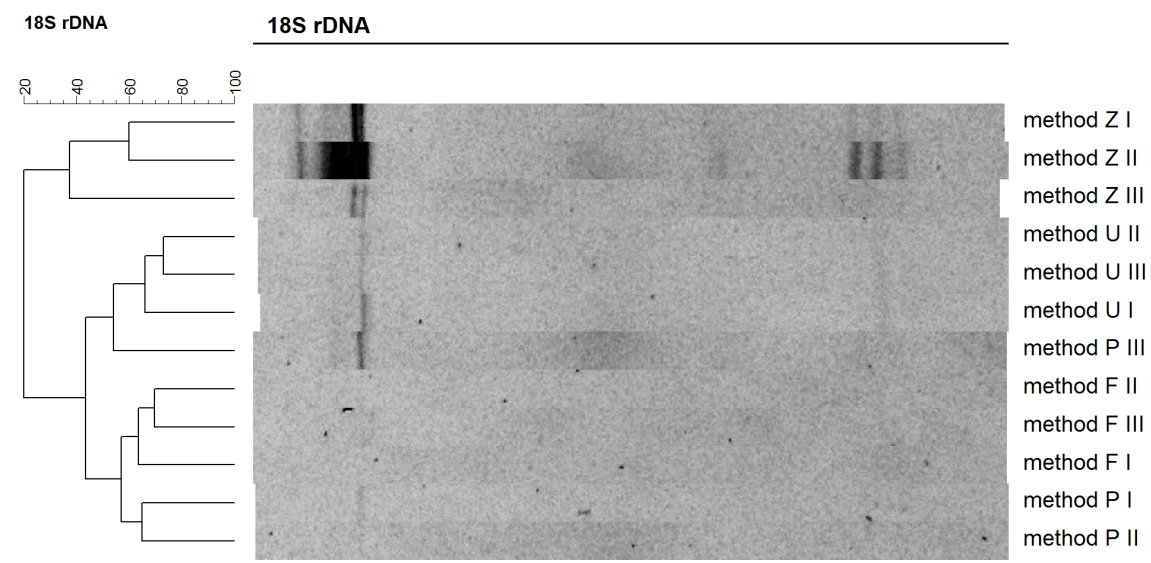

Figure 3. DGGE profiles of PCR-amplified SSU rRNA gene fragments of Eukarya. Triplicate samples are used. Clustering analysis was based on Pearson's correlation index and the unweighted pair-group method with arithmetic averages. Method F: FastDNA SPIN Kit for soil. Method P: PowerSoil DNA Isolation Kit. Method Z: ZR Soil Microbe DNA Kit .Method U UltraClean Plant DNA Isolation Kit. 


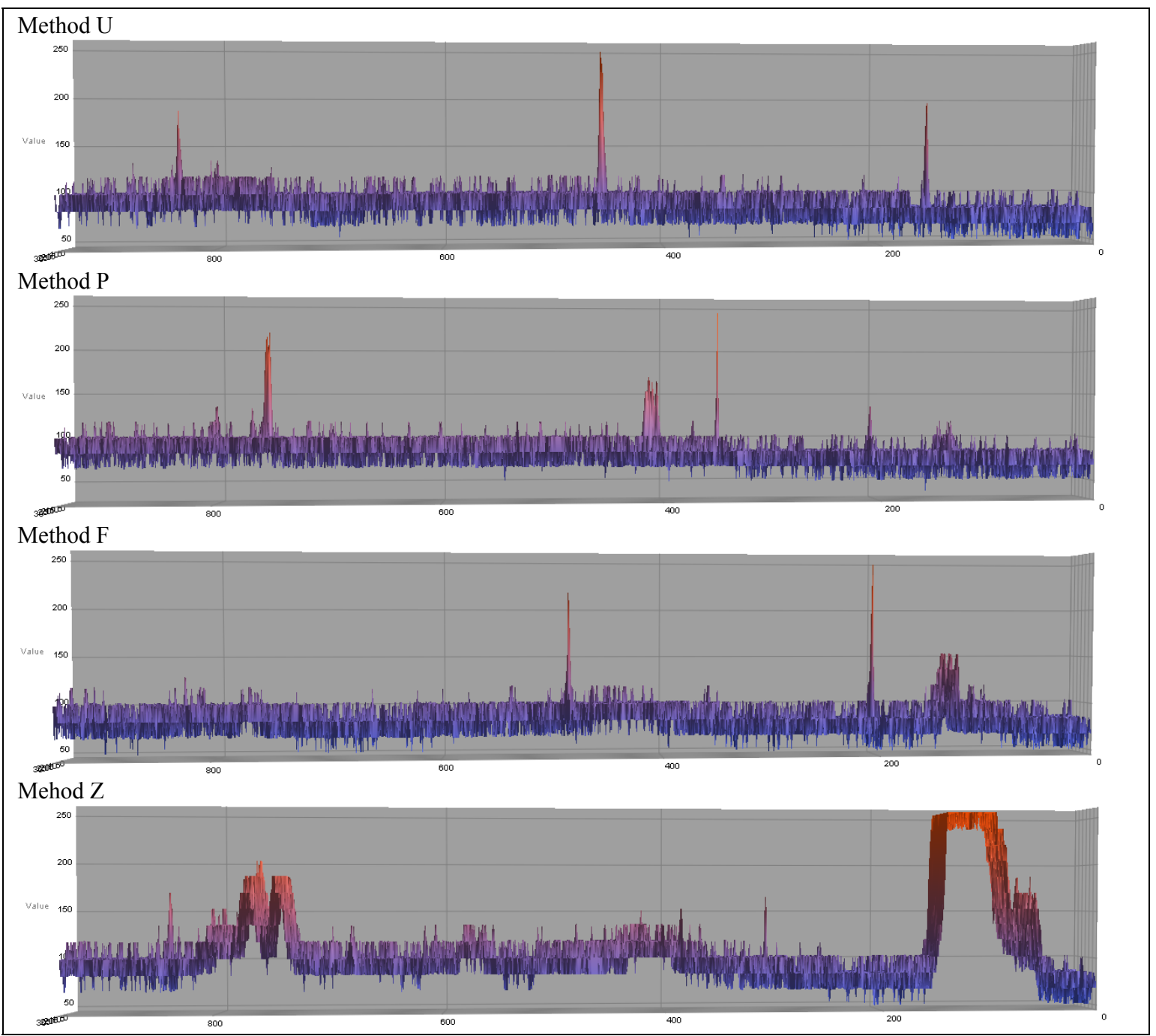

Figure 4. Intensity of bands in the DGGE profiles of PCR-amplified SSU rRNA gene fragments of Eukarya evaluated by the program BioNumerics.

\section{DISCUSSION}

The use of molecular biology methods for the analysis of microbial communities in environmental samples requires efficient and reproducible strategies of DNA extraction. There are many commercial kits for DNA extraction with different methodologies (16). This study showed significant differences in the efficiency of DNA extraction from coral samples with four commercial kits tested, that have previously been used in studies of coral microbiology $(3,5,14,18,23,25)$.

Different extraction methods may vary in terms of efficiency, depending on the challenges posed by the physical and chemical matrix of the sample. Consequently, the analysis of microbial community diversity or the quantification of specific genes is influenced by the DNA extraction method, reflected in its efficiency $(1,15,16)$. For instance, (12) Inceoglu and colleagues (2010) tested four different methods of DNA extraction from samples from three contrasting agricultural soils. Molecular analyses (PCR-DGGE and clone libraries) focusing on different microbial groups were used. This study revealed that the DNA extraction method strongly affects the results of studies on diversity and structure of soil 
microbial community. Each extraction method tested revealed differences in bacterial diversity, depending on the soil and the target group. For example, one of the methods tested was suitable for the extraction of Actinobacteria, even extracting DNA of novel groups, which had not been detected by other methods. Hu et al. 2010 (10), compared four different methods of DNA extraction from soil namely SDS-hyperhaline method (I), modified SDS-hyperhaline method (II), indirect method (III), alkaline lysis method (IV), and found that in this case and in accordance with the approaches tested the method IV showed better results both quantitatively and qualitatively.

In our study, we investigated the workability of different DNA extraction methods on coral. Among the four kits tested, method Z (Zr soil microbe short DNA kit protocol) was the most efficient with respect to the amount of DNA that was obtained from the coral. The DNA concentrations obtained in the final extracts were significantly higher than those obtained with the other protocols. Also, method $\mathrm{Z}$ was a fast protocol. Methods F (Fast DNA SPIN kit for soil), U (UltraClean plant DNA isolation kit) and $\mathrm{P}$ (PowerSoil DNA isolation kit) yielded lower concentrations of DNA after extraction. The advantage of the method $\mathrm{Z}$ is that it is designed to efficiently extract DNA from soil with large amounts of humic matter. For this reason, the method is based on a more elaborate purification step, with the goal of eliminating the humic material. Mahmoudi et al. (2011) (13) tested four commercial soil DNA extraction kits (UltraClean Soil DNA Isolation kit, PowerSoil DNA Isolation kit, PowerMax Soil DNA Isolation kit, and FastDNA SPIN kit) in PAH-contaminated soils. They described that the FastDNA SPIN kit provided significantly higher DNA yields for all soils; however, it also resulted in the highest levels of humic acid contamination.

Another advantage of method $\mathrm{Z}$ was that it extracted similar amount of DNA between replicates, in contrast to methods $\mathrm{P}$ and $\mathrm{F}$. This feature is extremely important, because differential extraction from the same sample can generate false differences between replicates inducing a bias in the subsequent analyses.

The results obtained by PCR-DGGE analysis of the coralassociated bacterial communities showed a clear influence of the different extraction methods on the apparent bacterial diversity and community composition. Method F, for example, which has been used to obtain DNA from different types of coral samples $(3,18)$, did not cover the bacterial diversity of our sample with the same efficiency as methods $\mathrm{Z}, \mathrm{P}$ and $\mathrm{U}$, generating a less rich band profile for Bacteria and failing to detect any band on the DGGE of micro-Eukaryotes. Method Z, besides having a larger amount of extracted DNA, revealed the most intense bands in the DGGE gel from bacteria. Furthermore, this method identified all bands present in other methods and some bands were only detected by method Z Another important feature was related to the grouping of replicates of the different methods tested. Method $\mathrm{Z}$ showed a close grouping between replicates, which is a critical in studies of microbial ecology.

The disparity between the kits tested in this study was clearer when considering the results of the micro-eukaryotic PCR-DGGE. Method F showed no bands in the DGGE gel which can lead to an underestimation of the microbiota. Methods $\mathrm{U}$ and $\mathrm{P}$ also showed lower efficiencies (fewer bands) compared to method Z. Diversity and abundance of microeukaryotes associated with coral might also be underestimated using these methods.

Choosing the most appropriate method for DNA extraction is very important, and one should be stimulated to always pursue the visualization of the greatest diversity of microorganisms in the sample. In spite of the fact that the Fast DNA Spin kit for soil has been successfully used for other samples $(4,8,21,22,25)$, even when compared with other strategies (1), it did not appear to be the best tool for the analysis of coral-associated microbial communities. Considering the comparative evaluation of the four methods used in this study, we suggest that the $\mathrm{Z}$ method is most indicated for the study of the microbial community of corals. 


\section{ACKNOWLEDGEMENTS}

This work was developed during the microbiology specialization course of Brazilian Society of Microbiology attended by researchers from the Biotechnology Section of Petrobras Research Center, CENPES. Thus, we thank the Brazilian Society of Microbiology and CENPES for the financial support and Projeto Coral Vivo for logistical support to this study, through its sponsorship from Petrobras and Arraial d'Ajuda Eco Parque. The authors also thank CAPES, CNPq (fellowships and Project 558372209/6) and FAPERJ for fellowships and financial support.

\section{REFERENCES}

1. Ariefdjohan, M.W.; Savaiano, D.A.; Nakatsu, C.H. (2010). Comparison of DNA extraction kits for PCR-DGGE analysis of human intestinal microbial communities from fecal specimens. Nutr. J. 22, 9-23.

2. Bourne, D.G.; Garren, M.; Work, T.M.; Rosenberg, E.; Smith, G.W.; Harvell, C.D. (2009). Microbial disease and the coral holobiont. Trends Microbiol. 17, 554-562.

3. Castro, A.P.; Araújo, S.D.Jr.; Reis, A.M.; Moura, R.L.; Francini-Filh, R.B.; Pappas, G.Jr.; Rodrigues, T.B.; Thompson, F.L.; Krüger, R.H. (2010). Bacterial Community Associated with Healthy and Diseased Reef Coral Mussismilia hispida from Eastern Brazil. Microb. Ecol. 59 (4), 658-67.

4. Cury, J.C.; Araujo, F.V.; Coelho-Souza, S.A.; Peixoto, R.S.; Oliveira, J.A.L.; Santos, H.F.; Da'vila, A.M.R.; Rosado, A.S. (2011). Microbial Diversity of a Brazilian Coastal Region Influenced by an Upwelling System and Anthropogenic Activity. Plos One 6 (1) e16553.

5. Garren, M.; Raymundo, L.; Guest, J.; Harvell, C.D.; Azam, F. (2009). Resilience of Coral-Associated Bacterial Communities Exposed to Fish Farm Effluent. Plos One 4 (10) e7319.

6. Graham, N.A.J.; Nash, K.L.; Kool, J.T. (2011). Coral reef recovery dynamics in a changing world. Coral Reefs 30, 283-294.

7. Handelsman, J.; Tiedje, J.M.; Alvarez-Cohen, L.; Ashburner, M.; Cann, I.K.O.; Delong, E.F.; Doolittle, W.F.; Fraser-Liggett, C.M.; Godzik, A.; Gordon, J.I.; Riley, M.; Schmidt, T.M. (2007). The new science of metagenomics: Revealing the secrets of our microbial planet. Washington, DC: The Nat. Acad. Press.

8. Hardoim, C.C.P.; Costa, R.; Araújo, F.V.; Hajdu, E.; Peixoto, S.P.; Lins, U.; Rosado, A.S.; van Elsas, J.D. (2009). Diversity of Bacteria in the Marine Sponge Aplysina fulva in Brazilian Coastal Waters. Appl.
Environ. Microb. 75 (10), 3331-3343.

9. Heuer, H.; Smalla, K. (1997). Application of denaturing gradient gel electrophoresis (DGGE) and temperature gradient gel electrophoresis (TGGE) for studying soil microbial communities. In: Van Elsas, J.D.; Trevors, J.T.; Wellington, E.M.H. (eds). Modern Soil Microb. Marcel Dekker, Inc.: New York, pp 353-373.

10. Hu, Y.; Liu, Z.; Yan, J.; Qi, X.; Li, J.; Zhong, S.; Yu, J.; Liu, Q. (2010). A developed DNA extraction method for different soil samples. J. Basic Microbiol. 50 (4), 401-7.

11. Hughes, T.P.; Baird, H.A.; Bellwood, D.R.; Cartão, M.; Connolly, S.R.; Folke, C.; Grosberg, R.; Hoegh-Guldberg, O.; Jackson, J.B.C.; Kleypas, J.; Lough, J.M.; Marshall, P.; Nyström, M.; Palumbi, S.R.; Pandolfi, J.M.; Rosen, B.; Roughgarden, J. (2003). Climate Change, Human Impacts, and the Resilience of Coral Reefs. Science 301 (5635), 928-933.

12. Inceoglu, O.; Hoogwout, E.F.; Hill, P.; van Elsas, J.D. (2010). Effect of DNA extraction method on the apparent microbial diversity of soil. Appl. Environ. Microbiol. 76 (10), 3378-3382.

13. Mahmoudi, N.; Slater, G.F.; Fulthorpe, R.R. (2011). Comparison of commercial DNA extraction kits for isolation and purification of bacterial and eukaryotic DNA from PAH-contaminated soils. Can. J. Microbiol. 57 (8), 623-628.

14. Meron, D.; Atias, E.; Kruh, L.I.; Elifantz, H.; Minz, D.; Fine, M.; Banin, E. (2011). The impact of reduced $\mathrm{pH}$ on the microbial community of the coral Acropora eurystoma. ISME J. 5, 51-60.

15. Moberg, F.; Folke, C. (1999). Ecological goods and services of coral reef ecosystems. Ecol. Eco. 29, 215-233.

16. Park, J.W.; Crowley, D.E. (2005). Normalization of soil DNA extraction for accurate quantification of target genes by real-time PCR and DGGE. BioTechniques (38), 579-586.

17. Porter, J.W.; Tougas, J.I. (2001). Reef ecosystems: threats to their biodiversity. In: Encyclopedia of Biodiversity, Levin, S.A. (eds.), San Diego: Academic Press, pp. 73-95.

18. Reis, A.M.; Araújo, S.D.Jr.; Moura, R.L.; Francini-Filho, R.B.; Pappas, G.Jr.; Coelho, A.M.; Krüger, R.H.; Thompson, F.L. (2009). Bacterial diversity associated with the Brazilian endemic reef coral Mussismilia braziliensis. J. Appl. Microbiol. 106 (4), 1378-87.

19. Rohwer, F.; Seguritan, V.; Azam, F.; Knowlton, N. (2002). Diversity and distribution of coral-associated bacteria. Mar. Ecol. Prog. Ser. 243, 1-10.

20. Rosenberg, E.; Koren, O.; Reshef, L.; Efrony, R.; Zilber-Rosenberg, I. (2007). The role of microorganisms in coral health, disease and evolution. Nat. Rev. Microbiol. 5, 355-362.

21. Santos, H.F.; Cury, J.C.; Carmo, F.L.; Rosado, A.S.; Peixoto, R.S. (2010). 18S rDNA Sequences from Microeukaryotes Reveal Oil Indicators in Mangrove Sediment. Plos One 5 ( 8) e12437.

22. Santos, H.F.; Cury, J.C.; Carmo, F.L.; Santos, A.L.; Tiedje, J.; van Elsas, J.D.; Rosado, A.S.; Peixoto, R.S. (2011). Mangrove Bacterial Diversity and the Impact of Oil Contamination Revealed by Pyrosequencing: 
Bacterial Proxies for Oil Pollution. Plos One 6 (3) e16943.

23. Sato, Y.; Willis, B.L.; Bourne, D.G. (2010). Successional changes in bacterial communities during the development of black band disease on the reef coral, Montipora hispida. ISME J. 4, 203-214

24. Teixeira, L.C.R.S.; Peixoto, R.S.; Cury, J.C.; Sul, W.J.; Pellizari, V.H.; Tiedje, J.D.; Rosado, A.S. (2010). Bacterial diversity in rhizosphere soil from Antarctic vascular plants of Admiralty Bay, maritime Antarctica.
ISME J. 4, 989-1001.

25. Wegley, L.; Edwards, R.; Rodriguez-Brito, B.; Liu, H.; Rohwer, F. (2007). Metagenomic analysis of the microbial community associated with the coral Porites astreoides. Environ. Microbiol. 9 (11), 2707-2719.

26. Wilkinson, C.; Souter, D. (2008). Status of Caribbean coral reefs after bleaching and hurricanes in 2005. Global Coral Reef Monitoring Network, and Reef and Rainforest Research Centre, Townsville. 